\title{
Heterotrophy in corals: zooplankton predation by the hydrocoral Millepora complanata
}

\author{
John B. Lewis \\ Department of Biology, McGill University, 1205 Dr Penfield Avenue, Montreal, Quebec, Canada H3A 1B1
}

\begin{abstract}
Heterotrophy is examined in the hydrocoral Millepora complanata Lamarck and compared with scleractinian corals. Natural zooplankton catch rates and digestion rates were determined from counts of prey items captured by the gastrozooids on surfaces of millepore colonies collected in the field. The mean catch rate or feeding rate $( \pm S D)$ was $7.1 \pm 4.10$ prey items $\mathrm{cm}^{-2}$ surface $\mathrm{d}^{-1}$ and complete digestion of prey required about $24 \mathrm{~h}$. Copepods comprised the bulk (63\%) of the diet. Based on the argument that measured catch rates of corals are highly variable because of plankton patchiness, and the assumption that millepore colonies with expanded zooids feed both day and night, a potential feeding or catch rate was derived from the mean number of gastrozooids on the colonies times the digestion rate. Daily food consumption estimated from the potential catch rates exceeded estimates of daily energy needed for respiration by a factor of 6.7. It was concluded that heterotrophic feeding in $M$. complanata can potentially supply more than the daily energy requirements of the hydrocoral and may exceed feeding rates of scleractinian corals.
\end{abstract}

\section{INTRODUCTION}

Much of the recent research on nutritional strategies of scleractinian corals has been directed towards autotrophy (see review by Muscatine 1990). Less information is available on heterotrophic modes of feeding in spite of the early conclusions of Yonge (1930) that corals are highly specialized carnivores and subsequent arguments that corals have a polytrophic feeding strategy (Muscatine 1973, Porter 1976, Muscatine \& Porter 1977, Sorokin 1990). Estimates of the potential autotrophic carbon uptake of shallow water corals vary between 78 and $161 \%$ of the amount needed for respiration (Muscatine 1990) but often fall short of estimated total energy requirements except in very shallow water (Davies 1977, 1980, McCloskey \& Muscatine 1984). In at least one species, the common Caribbean coral Montastrea annularis, substantial amounts of exogenous food are required to meet total demands (Porter 1985, Szmant 1991). On the other hand, Edmunds \& Davies (1986) found no evidence for heterotrophic feeding in the common Atlantic coral Porites porites and concluded that this species was largely autotrophic. Thus, although the ability of reef corals to capture food from the surrounding water is recog- nized, the relative importance of autotrophy and heterotrophy remains unresolved and varies with species and habitat (Porter 1976, Muscatine 1990, Jackson 1991, Sebens \& Johnson 1991)

Although little is known about heterotrophy in hydrocorals, they are reported to be voracious plankton feeders (Abe 1938, de Kruijf 1975). Feeding behavior and responses to chemical and tactile stimuli are similar to those of other hydrozoans (de Kruijf 1975). The purpose of the present study is to examine and quantify heterotrophy in the hydrocoral Millepora complanata Lamarck and to compare it with feeding in scleractinian corals. Feeding rates are determined from catches of natural zooplankton prey counted on colonies freshly collected in the field. The variability of catch rates is discussed in relation to zooplankton patchiness, a potential feeding or catch rate is proposed and a heterotrophic energy budget is estimated.

\section{MATERIALS AND METHODS}

Field observations, experiments and specimen collections were carried out on fringing coral reefs in the northern sector of the west coast of Barbados which is 
Table 1. Millepora complanata. Diel variation in catch [mean no. of zooplankton prey items $\mathrm{cm}^{-2}$ colony surface ( $\pm \mathrm{SD}$ )]

\begin{tabular}{lcccccc|}
\hline Time $(\mathrm{h})$ & $06: 00-08: 00$ & $08: 00-10: 00$ & $10: 00-12: 00$ & $12: 00-14: 00$ & $14: 00-16.00$ & $16: 00-18: 00$ \\
Catch & $7.44(4.12)$ & $5.92(3.88)$ & $6.06(5.24)$ & $8.22(4.22)$ & $8.44(4.64)$ & $6.50(4.58)$ \\
Area & 236 & 222 & 262 & 262 & 232 & 19 \\
No. of colonies sampled & 17 & 15 & 15 & 18 & & 15 \\
a Surtace area examined $\left(\mathrm{cm}^{2}\right)$ & & & & & \\
\hline
\end{tabular}

least affected by eutrophication (Tomascik \& Sander 1985). Actively feeding colonies of Millepora complanata were located in the field by the presence of densely packed, expanded zooids which gave the surfaces of the colonies the appearance of white felt. Close inspection of the surface of these colonies underwater and in the laboratory showed that zooplankters were attached to the hydrocoral zooids. Expanded colonies were observed routinely at night as well as during daytime.

In order to determine if there were any differences in feeding activity during the day, the number of feeding colony branches (upright blades or plates) of Millepora complanata with clearly visible, well expanded zooids covering a minimum of 10 to $15 \%$ of colony surfaces were counted along $10 \times 1 \mathrm{~m}$ transects. Basal, encrusting portions of colonies were not included because of surface irregularity, fission, and mortality, which caused difficulty in establishing colony surface area limits. However, encrusting portions of colonies bear zooids (de Weerdt 1984) which were expanded. Transects were established perpendicular to the shore at 2 to $4 \mathrm{~m}$ depth, near the mid-reef crest where the hydrocoral is most abundant (Lewis 1991). Ten transects were marked out and the number of expanded and contracted colony branches recorded at different times during the morning and afternoon under a variety of prevailing sea and weather conditions during a period of about 1 mo.

The abundance and identity of captured prey were determined from branches freshly collected from the transect sites at $2 \mathrm{~h}$ intervals between 06:00 and 18:00 h (see Table 1) over an 8 wk period. Separate, upright branches from non-contiguous colonies with well expanded zooids were broken off near their bases and removed in individual plastic bags within $30 \mathrm{~min}$ to the laboratory where they were preserved immediately in $5 \%$ buffered formalin. Attached prey organisms and visible ingested prey were counted along 3 vertical strips, $1 \mathrm{~cm}$ wide, on the surfaces of both sides of the sampled blades. The number of prey items captured (the catch) was expressed in units of coral skeleton surface area. Gastrozooid (feeding polyps) contents were not egested upon preservation. De Kruijf (1975) reported that the capture of more than one prey item at a time by a single gastrozooid was unlikely because zooids fold inwards and retract following contact. Although dactylozooids have the potential for capturing prey, de Kruijf (1975) observed no directed or coordinated movement towards gastrozooids and concluded that dactylozooids have a purely defensive function.

In order to ascertain the rate of prey digestion, 25 upright branches from separate colonies with well expanded zooids were selected. Five of these branches were collected at 06:00 h and preserved in formalin. The remaining 20 blades were covered by plastic bags held tightly at the branch bases by elastic bands to exclude plankton and remained in situ for periods of 6,12 and 24 h respectively. Tests with soluble dye injected at the bases of several bags showed that the enclosed water cleared within $30 \mathrm{~min}$, indicating continuous, slow water circulation within the bags. A set of the bagged colonies was collected from the reef at the end of each closure period and preserved in formalin before counting the captured prey. Examination of each colony branch was completed within 24 h so as ensure observation of fresh material. Digestion time is defined as the period between capture of a prey item and the time the prey could no longer be recognized in the gastrozooids (Purcell 1989). All colonies were examined with a Wild M-5 stereomicroscope at 60 to $200 \times$ magnification.

\section{RESULTS}

Of the total of 1400 colony blades examined among all transects, $65 \%$ were well-expanded for feeding. There were no significant differences in the percent of expanded and contracted colonies either diurnally or among days. The difference between morning and afternoon pooled means of percentages of expanded colonies (arc-sine transformed for normality) was not significant at the 0.01 level $(t=1.69, \mathrm{df}=29)$. Similarly, a 1-way ANOVA showed no significant differences in percentages of expanded colonies among days $\left(F_{7,21}=\right.$ $3.34, \mathrm{p}>0.01$ ).

The mean catch $( \pm \mathrm{SD}$ ) for daytime samples collected between $06: 00$ and $18: 00 \mathrm{~h}$ was $7.10 \pm 4.10$ prey $\mathrm{cm}^{-2}$ colony surface with a range between 0 and 25 prey $\mathrm{cm}^{-2}$ (Table 1). A 2-way ANOVA testing for differences 
Table 2. Millepora complanata. Rate of prey digestion

\begin{tabular}{|lcccc|}
\hline Sampling interval (time colony covered) & $0 \mathrm{~h}$ & $6 \mathrm{~h}$ & $12 \mathrm{~h}$ & $24 \mathrm{~h}$ \\
Mean prey $\mathrm{cm}^{-2}$ ( \pm SD) & $1.98(0.88)$ & $1.34(0.84)$ & $0.70(0.46)$ & $0.18(0.11)$ \\
\% Initial prey & 100 & 68 & 36 & 9 \\
\% Prey digested & 0 & 32 & 64 & 91 \\
Total prey & 788 & 429 & 156 & 6 \\
No. of colonies sampled & 5 & 8 & 6 & 6 \\
\hline
\end{tabular}

in means of catches of prey items among sampling times and among days showed no significant differences in catches among $2 \mathrm{~h}$ intervals $\left(F_{5.15}=0.92\right.$, $p>0.01$ ), thus supporting the conclusion that there were no diel differences in feeding activity. Catches among days were significantly different $\left(F_{4,16}=6.68\right.$, $\mathrm{p}<0.01$ )

Means of catches counted on colony branches enclosed in plastic bags for 6 to 24 h are shown in Table 2 . No freshly caught prey were observed on expanded zooids of bagged colonies. Means of catches were significantly different among treatment intervals (ANOVA; $F_{3,56}=30.72, p<0.01$ ). Tukey's studentized range tests showed that 12 and $24 \mathrm{~h}$ interval means were significantly lower than the initial catch at the 0.01 level and that the $24 \mathrm{~h}$ interval mean was significantly lower than the $12 \mathrm{~h}$ mean $(\mathrm{p}<0.01)$. The number of prey digested during each $6 \mathrm{~h}$ interval is also expressed as a percent of the initial catch counted at the beginning of the experimental treatment (Table 2). Digestion was $32 \%$ completed at the end of $6 \mathrm{~h}, 64 \%$ completed in $12 \mathrm{~h}$ and $91 \%$ completed at the end of $24 \mathrm{~h}$

The composition of the prey captured by Millepora complanata is shown in Table 3 . Copepods comprised $63 \%$ of the total catch and $36 \%$ consisted of unidentified partially digested items.

\section{DISCUSSION}

The majority of reef corals feed principally at night; feeding on zooplankton is continuous as long as the

Table 3. Millepora complanata. Percent composition of zooplankton prey items $(\mathrm{N}=9989)$

\begin{tabular}{lr|}
\hline Taxa & Percent of total \\
\hline Pelecypod veligers & $<1$ \\
Amphipods & $<1$ \\
Gastropod veligers & 1 \\
Unidentified copepods & 39 \\
Macrosetella and Microsetella spp. & 9 \\
Oithona spp. & 7 \\
Copepod egg clusters & 7 \\
Unidentified partially digested items & 36 \\
\hline
\end{tabular}

polyps are expanded (Yonge 1930, Goreau 1956, Coles 1969, Muscatine 1973, Porter 1974). In Millepora complanata, the expansion of colonies both day and night, the presence of fresh and partially digested prey in the gastrozooids in the early morning (06:00 h) and the lack of any diel differences in prey capture rates (Table 1) confirm that this hydrocoral can feed both during the day and at night.

If feeding occurs throughout the full diurnal cycle and is continuous as long as the zooids are expanded (de Kruijf 1975), and because digestion requires about $24 \mathrm{~h}$ to complete (Table 2), then a daily feeding or catch rate can be calculated simply from the number of captured prey per unit surface area of a colony. Digestion times appear to be too long to allow zooid multiple prey capture and thus each visible zooid catch is the ration captured during a $24 \mathrm{~h}$ period. A mean catch rate can thus be calculated as $7.1 \pm 4.1$ prey $\mathrm{cm}^{-2}$ colony branch surface $\mathrm{d}^{-1}$.

Because catches were highly variable among days, the question arises as to whether the measured mean catch rate of Millepora complanata is representative of catches over long periods. Mackenzie et al. (1990) pointed out the many difficulties in estimating field consumption rates by planktivores and emphasized the importance of prey density and encounter rates. We would thus expect capture rates by $M$. complanata to be partly dependent upon zooplankton prey densities in the water, and the differences in daily catches will be affected by variation in plankton prey abundances. Purcell (1981) reported that in siphonophores, the number of prey ingested by the gastrozooids was correlated with the abundance of prey in the surrounding water. Because there is a high temporal variability in zooplankton numbers and biomass on reefs (Alldredge \& King 1977, Hobson \& Chess 1986, Lewis \& Boers 1991), capture estimates obtained from a small number of tests will likely be biased by the low sampling frequency (Haury et al. 1978). Variability of feeding rates will be partly a consequence of plankton patchiness. Previous estimates of feeding rates in corals based on gut examinations (Porter 1974) and feeding responses (Johannes \& Tepley 1974) were determined over short time intervals on a few occasions and may not have been representative of long term catch rates. Unless more replicate observations can be ob- 
tained to reduce sampling error, an alternative method of estimating capture rates must be sought.

If feeding occurs as long as zooids are expanded (de Kruijf 1975 ) then a potential feeding or potential catch rate may be estimated from the mean number of gastrozooids per unit surface area of the millepore corallum times the rate of digestion of the prey. Sebens (1987) argued that for prey such as copepods, capture rates are proportional to contact rates and to the surface area used in feeding. The mean density of gastropores counted on 10 colony blades of Millepora complanata was $48 \pm 12.6 \mathrm{~cm}^{-2}(\mathrm{~N}=500)$. A range of densities of between 10 and $70 \mathrm{~cm}^{-2}$ was reported by de Weerdt (1984). Because digestion of prey requires about $24 \mathrm{~h}$ (Table 2), the mean potential catch rate would be $48 \pm 12.6$ prey items $\mathrm{cm}^{-2}$ surface area $\mathrm{d}^{-1}$. It should be noted however, that rates of prey capture may be affected by water movement and other factors (Sebens \& Johnson 1991).

Millepora complanata is an opportunistic feeder insofar as the diet consisted largely of copepods (Table $3)$, the most abundant zooplankton group in neritic waters at Barbados (Sander \& Moore 1978, Lewis \& Boers 1991). Copepod numbers are highly variable however, and high copepod densities only occur at low frequencies (Lewis \& Boers 1991). Nevertheless, the high percentage of swarming species of Oithona in the diet suggests that $M$. complanata could take advantage of copepod aggregations known to occur over reefs (Hamner \& Carleton 1979). Bamstedt (1990) reported that the scyphozoan Aurelia aurita had to depend on the exploitation of zooplankton aggregations because average prey densities were so low.

While the rates of digestion by millepores have not been reported previously, de Kruijf (1975) proposed that digestion would take more than several hours. Rates of digestion of prey (from $32 \%$ in $6 \mathrm{~h}$ to $91 \%$ in $24 \mathrm{~h}$ ) by Millepora complanata appear to be substantially slower than those reported for octocorals which digested zooplankton in 4 to 6 h (Sebens \& Koehl 1984) and scleractinian corals which varied between 3 and 13 h (Yonge \& Nicholls 1931 Porter 1978). The slow digestion by $M$. complanata may be partly due to the small size of the zooids 0.2 to $0.3 \mathrm{~mm}$ oral disk diameter) which would be expected to contain relatively less digestive tissue than do the larger polyps of scleractin- ian corals. The large prey size ( 1 to $2 \mathrm{~mm}$ for Oithona spp.) relative to the small zooids would also be expected to slow ingestion and digestion.

The daily food consumption or energy intake of Millepora complanata can be estimated from the mean daily catch rate and adult copepod dry weights. Conventions and data scources used to estimate consumption and respiration are shown in Table 4 . The mean daily energy consumption of $M$. complanata is (7.10 prey $\mathrm{cm}^{-2} \mathrm{~d}^{-1}$ ) $\times$ mean adult copepod dry wt $(20.60 \mu \mathrm{g})=0.15 \mathrm{mg}$ dry wt or $3.40 \mathrm{~J} \mathrm{~cm}^{-2} \mathrm{~d}^{-1}$. This rate is higher than values of $0.59 \mathrm{~J} \mathrm{~cm}^{-2} \mathrm{~d}^{-1}$ for the scleractinian Porites lobata (Johannes \& Tepley 1974) and $1.84 \mathrm{~J} \mathrm{~cm}^{-2} \mathrm{~d}^{-1}$ for Monastrea cavernosa (Porter 1974). Similarly, a potential consumption rate for $M$. complanata may be determined from the potential catch rate (48 prey $\mathrm{cm}^{-2} \mathrm{~d}^{-1}$ ) $\times$ mean adult copepod dry wt $(20.60 \mu \mathrm{g})=1 \mathrm{mg}$ dry wt or $23.40 \mathrm{~J} \mathrm{~cm}^{-2} \mathrm{~d}^{-1}$ Thus, on the basis of a potential feeding rate, the heterotrophic energy intake of the hydrocoral $M$. complanata may greatly exceed that of scleractinian corals.

If energy consumption and respiration rates of millepores are known, it is possible to estimate whether daily food intake is adequate to fulfill daily metabolic energy requirements. Note however, that a number of following assumptions are based on metabolic data from scleractinian corals and should be viewed with caution when applied to millepores. Respiration rates have been determined for a number of species of millepores and all are comparable to the measured rates of scleractinian corals (McCloskey et al. 1978). Only the data for Millepora alcicornis (Beyers 1966) can be normalized to colony surface area values and yield a mean rate of $0.31 \mathrm{mg}$ oxygen $\mathrm{cm}^{-2} \mathrm{~d}^{-1}$ for whole colony respiration. If it is assumed that $70 \%$ of whole colony respiration is animal respiration (based on scleractinian corals; Lewis 1981) and that the rate of respiration of $M$. complanata is about the same as that of $M$. alcicornis, then the mean rate for $M$. complanata animal tissue is $0.22 \mathrm{mg}$ oxygen $(3.49 \mathrm{~J}) \mathrm{cm}^{-2} \mathrm{~d}^{-1}$. The ratio of measured energy consumption $(3.40 \mathrm{~J})$ to respiration $(3.49 \mathrm{~J})$ is 0.97 and that of potential consumption $(23.40 \mathrm{~J})$ to respiration $(3.49 \mathrm{~J})$ is 6.70 . Heterotrophic feeding in $M$. complanata could thus potentially supply more than 6 times the amount of energy required for respiration.

Table 4. Conventions and data sources used to estimate potential feeding rates and respiration of Millepora complanata

Mean ( \pm SD) dry wt of adult demersal copepods collected at Barbados $=20.60 \pm 2.5 \mu \mathrm{g}$ $1 \mathrm{mg}$ dry wt mixed tropical copepods $=23.40 \mathrm{~J}$ $1 \mathrm{ml}$ oxygen $=19.63 \mathrm{~J}$
Lewis \& Boers (1991)

Chisholm \& Roff (1990)

Edmunds \& Davies (1986) 
Acknowledgements. I am grateful to Dr Euna Moore of the University of the West Indies, Barbados, who identified the species of copepod prey, to Dr Kenneth P. Sebens of the University of Maryland, USA, for his helpful comments on the manuscript, to Patrick Allard for field and laboratory assistance and to Dr Mayne Hunte for the provision of laboratory facilities at the Bellairs Research Institute of McGill University. The research was supported by a grant in aid of research from the Natural Sciences and Engineering Research Council of Canada.

\section{LITERATURE CITED}

Abe, N. (1938). Feeding behaviour and the nematocysts of Fungia and 15 other species of corals. Palao trop. biol. Stn. Stud. 1: 469-521

Alldredge, A. L., King, J. M. (1977). Distribution, abundance, and substrate preference of demersal reef zooplankton at Lizard Island Lagoon, Great Barrier Reef. Mar. Biol. 41: $317-333$

Bamstedt, U. (1990). Trophodynamics of the scyphomedusae Aurelia aurita. Predation rate in relation to abundance, size and type of prey organism. J. Plankton Res. 12: $215-229$

Beyers, R. J. (1966). Metabolic similarities between symbiotic coelenterates and aquatic systems. Arch. Hydrobiol. 62: 273-284

Chisholm, L. A., Roff, J. C. (1990). Size-weight relationships and biomass of tropical neritic copepods off Kingston, Jamaica. Mar. Biol. 106: 71-77

Coles, S. L. (1969). Quantitative estimates of feeding and respiration for three scleractinian corals. Limnol. Oceanogr. 14: $949-953$

Davies, P. S. (1977). Carbon budgets and vertical zonation of Atlantic reef corals. Proc. 3rd int. coral Reef Symp. 1. 392-396

Davies, P. S. (1980). Respiration in some Atlantic reef corals in relation to vertical distribution and growth form. Biol. Bull. 158: $187-194$

de Kruijf, H. A. M. (1975). General morphology and behaviour of gastrozoids and dactylozoids in two species of Millepora (Milleporina, Coelenterata). Mar. Behav. Physiol. 3: $181-192$

de Weerdt, W. H. (1984). Taxonomic characters in Caribbean Millepora species (Hydrozoa, Coelenterata). Bijdr Dierk. 54: $243-262$

Edmunds, P. J., Davies, P.S. (1986). An energy budget for Porites porites (Scleractinia). Mar. Biol. 92: 339-347

Goreau, T F. (1956). A study of the biology and histochemistry of corals. Ph. D. dissertation, Yale University, New Haven

Hamner, W. M., Carleton, J. H. (1979). Copepod swarms: attributes and role in coral reef ecosystems. Limnol. Oceanogr. 24: 1-14

Haury, L. R., McGowan, J. A., Wiebe, P. H. (1978). Patterns and processes in the time-space scales of plankton distribution. In: Steele, J. H. (ed.) Spatial pattern in plankton communities. Plenum Press, London, p. 227-327

Hobson, E. S., Chess, J. R. (1986). Diel movements of transient and resident zooplankters above the lagoon reef at Enewetak Atoll, Marshall Islands. Pacific Sci. 40:7-26

Jackson, J. B. C. (1991). Adaption and diversity of reef corals. Bioscience 41: 475-482

Johannes, R. E., Tepley, L. (1974). Examination of feeding of the reef coral Porites lobata in situ using time lapse photography. Proc. 2nd int. coral Reef Symp. 2: 127-131
Lewis, J. B. (1981). Estimates of secondary production of reef corals. Proc. 4th int coral Reef Symp. 2: 369-374

Lewis, J. B. (1991). Testing the coral fragment size-dependent survivorship hypothesis for the calcareous hydrozoan Millepora complanata. Mar. Ecol. Prog. Ser 70: 101-104

Lewis, J. B., Boers, J. J. (1991). Patchiness and composition of coral reef demersal zooplankton. J. Plankton Res. 13: $1273-1289$

Mackenzie, B. R., Leggett, W. C., Peters, R. H. (1990). Estimating larval fish ingestion rates: can laboratory derived values be reliably extrapolated to the wild? Mar. Ecol. Prog. Ser. 67: 209-225

McCloskey, L. R., Muscatine, L. (1984). Production and respiration in the Red Sea coral Stylophora pistillata as a function of depth. Proc. R. Soc. London (Ser. B) 222: 215-230

McCloskey, L. R., Wethey, D. S., Porter, J. W. (1978). Measurement and interpretation of photosynthesis and respiration in reef corals. In: Stoddart, D. R., Johannes, R. E. (eds.) Coral reefs: research methods. Monographs on oceanic methodology 5; UNESCO, Paris, p. 379-396

Muscatine, L. (1973). Nutrition of corals. In: Jones, O. A., Endean, R. (eds.) Biology and geology of coral reefs, Vol. II, Biology I. Academic Press, New York, p. 77-115

Muscatine, L. (1990). The role of symbiotic algae in carbon and energy flux in reef corals. In: Dubinsky, $z$. (ed.) Ecosystems of the world, Vol. 25, Coral reefs. Elsevier, Amsterdam, p. 75-87

Muscatine, L., Porter, J W. (1977). Reef corals: mutualistic symbioses adapted to nutrient-poor environments. BioSci 27: $454-460$

Porter, J. W. (1974). Zooplankton feeding by the Caribbean reef-building coral Montastrea cavernosa. Proc. 2nd int. coral Reef Symp. 2: 111-125

Porter, J. W. (1976). Autotrophy, heterotrophy, and resourse partitioning in Caribbean reef-building corals. Am. Nat. 110: $731-742$

Porter, J. W. (1978). Coral feeding on zooplankton. In: Stoddart, D. R., Johannes, R. E. (eds.) Coral reefs: research methods. Monographs on oceanic methodology 5 . UNESCO, Paris, p. 515-527

Porter, J. W. (1985). The maritime weather of Jamaica: its effect on annual carbon budgets of the massive reefbuilding coral Montastrea annularis. Proc. 5th int. coral Reef Congr. 6: 363-379

Purcell, J. E. (1981). Dietary composition and diel feeding patterns of epipelagic siphonophores. Mar. Biol. 65: 83-90

Purcell, J. E. (1989). Predation on fish larvae and eggs by the hydromedusa Aequorea victoria at a herring spawning ground in British Columbia. Can. J. Fish. Aquat. Sci. 46: $1415-1427$

Sander, F., Moore, E. (1978). A comparative study of inshore and offshore copepod populations at Barbados, West Indies. Crustaceana 35: 225-240

Sebens, K. P. (1987). Coelenterata. In: Pandian, T. J., Vernberg, F. J. (eds.) Animal energetics, Vol. 1 Academic Press, New York, p. 55-120

Sebens, K. P., Johnson, A. S. (1991). Effects of water movement on prey capture and distribution of reef corals. Hydrobiologia 226: 91-101

Sebens, K. P., Koehl, M. A. R. (1984). Predation on zooplankton by the benthic anthozoans Alcyonium siderium (Alcyonacea) and Metridium senile (Actiniaria) in the New England subtidal. Mar. Biol. 81: 255-271

Sorokin, Yu. I. (1990). Aspects of trophic relations, productivity and energy balance in coral-reef ecosystems. In: Dubinsky, Z. (ed.) Ecosystems of the world, Vol. 25, Coral reefs. Elsevier, Amsterdam, p. 401-410 
Szmant, A. M. (1991). Sexual reproduction by Caribbean reef corals Montastrea annularis and $M$. cavernosa. Mar. Ecol. Prog. Ser 74:13-25

Tomascik, T., Sander, F. (1985). Effects of eutrophication on reef-building corals. I. Growth rates of the reefbuilding coral Montastrea annularis. Mar. Biol. 87: $143-155$

This article was submitted to the editor
Yonge, C. M. (1930). Studies on the physiology of corals 1. Feeding mechanisms and food. Scienc Rep. Gt Barrier Reef Exped. 1: 13-57

Yonge, C. M., Nicholls, A. G. (1931). Studies on the physiology of corals. V. The effect of starvation in light on the relationship between corals and zooxanthellae. Scient. Rept. Gt Barrier Reef Exped. 1 177-211

Manuscript first received: November 26, 1991 Revised version accepted: November 30, 1992 